\title{
小耳症549例の臨床統計的観察
}

\author{
馬場 駿吉・梅田 敬子・北垣 徹・岡嶋 初枝
}

\section{Clinical and Statistical Analysis of 549 Patients with Microtia}

\author{
Shunkichi Baba, Keiko Umeda, Toru Kitagaki and Hatsue Okajima \\ (Nagoya City University Medical School)
}

We experienced 549 patients with microtia between 1968 and 1991.

Males distinctly predominated, with sex ratio being 9:5.

Of the 549 patients, the right ear was malformed in 319 and the left in 181, and malformation was bilateral in 49 .

In almost all patients with microtia, it was associated with congenital aural atresia or high-grade stenosis.

Seven cases of familial microtia were found, in which 3 of the fathers had cup-ears.

About $27 \%$ of the patients' mothers had had a cold, threatened spontaneous abortion, toxemia or other complication during their pregnancy.

No obvious genetic or environmental factors in the etiology of microtia were found.

Key words: microtia, statistical analysis, congenital aural atresia

はじめに

小耳症とは先天的に耳介が小さくかつ変形を 伴うものの総称である. 発生頻度は, 米国では Holmes ${ }^{1)}$ が20,000人に 1 人, Conway ${ }^{2)}$ が 12,500 人に 1 人と報告している. 本邦では, 福田ら ${ }^{3)}$ が 10,000 人に 1 人，黒木ら4) は 10,000 人に 2.1 人と推定されるとしており，比較的稀な疾患で ある。

その原因としては, 遺伝子の突然変異, 染色 体の異常, 妊娠初期のサリドマイド, 葉酸拮抗 剂の服用が報告されているが，多くの小耳症は 遺伝の法則には従わず，妊娠歴の調査によって も特定の原因がつきとめられないことが多い。 今回, 過去23年間に当科を受診した小耳症患 者549例に対し, 性別, 罹患側, 耳介変形度,
他の奇形との合併，家族内発生，妊娠中の異常， 薬物療法などについて統計的観察を行ったので， 若干の考察を加えて報告する.

\section{調查対象}

昭和 43 年 4 月より平成 2 年 12 月までに名古屋 市立大学耳鼻咽喉科を受診した小耳症患者549 例，598耳である。

\section{調査結果}

1 ) 性 別

男子 352 例（64.1\%)，女子197例（35.9\%） であった。

2 ）罹患側

罹患側別にわけると右側319例（58.1\%）, 左 側181例 (33.0\%)，両側49例（8.9\%）であっ た。性別, 罪患側を組み合わせて観察すると図 
1 のごとくで, 男子の右側に発生したものが最 も高い頻度を示した。

3 ) 重症度別分類

小耳症の重症度を荻野ら5) の基準（表 1，図 2 ）に従って 5 型に分類した.

また，外耳道奇形を合併するものが多く，外 耳道奇形については太田ら ${ }^{6)}$ の基準（表 2）に

表 1 小耳症の分類

(荻野洋一, 他 : 19795) より改変)

第 I 度 : 耳介各部の識別可能なもの

第 II 度 : 耳介の構造の一部が存在し中等度の奇形 を示すもののらち耳介窩を有するもの

第正度 : 中等度の奇形で耳介窩を有しないいわゆ る peanuts-shell type のもの

第 $\mathrm{N}$ 度 : 高度の奇形で耳垂のみわずかに形態を有 するもの

第 V度 : 無耳症

表 2 外耳道奇形の分類 (太田文彦，他：19656) より改変）

第 I 度 : 外耳道狭窄のみのもの

第度：骨部外耳道の及閉鎖し軟部外耳道の存 在するもの

第皿度 : 外耳道入口部に浅い陌凹を認めるもの 第 $\mathbb{N}$ 度 : 完全閉鎖のもの
従って 4 型に分類した.

小耳症は，第而度の peanuts-shell type が最 も多く，336耳（56.2\%）であった。また，小 耳症のらち $92.4 \%$ は何らかの外耳道奇形を伴っ ていて，そのらち71.4\%は外耳道完全閉鎖であ った（表 3 ）。軽度の小耳症のものは外耳道奇 形も軽く, 重度の小耳症のものは外耳道奇形も

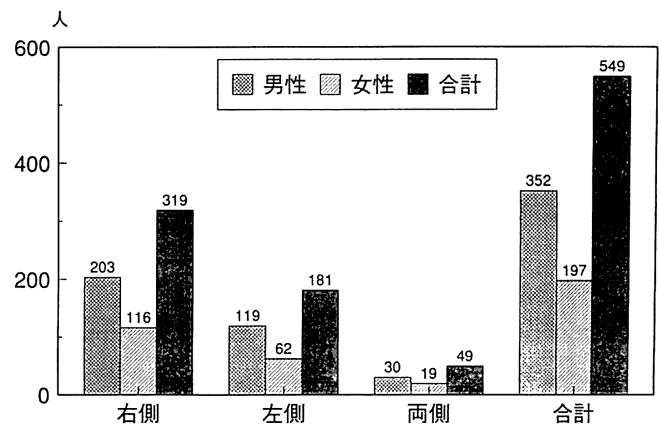

図 1 性別, 罹患側

第 I 度 第 II度 第III度 第 $\mathrm{V}$ 度 第 V 度

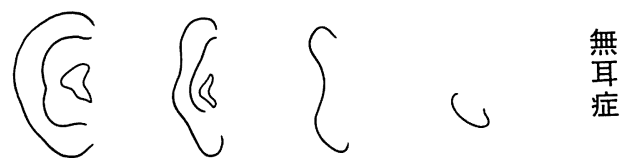

図2 小耳症の分類 (荻野)

表 3 耳介奇形と外耳道奇形の相関

\begin{tabular}{|c|c|c|c|c|c|c|c|}
\hline & & \multicolumn{2}{|c|}{ 外 } & 道 & \multicolumn{3}{|l|}{ 形 } \\
\hline & & normal & $\mathrm{I}^{\circ}$ & II $^{\circ}$ & III $^{\circ}$ & $\mathbb{N}^{\circ}$ & Total \\
\hline \multirow[b]{2}{*}{ 小 } & $I^{\circ}$ & $\begin{array}{c}30 \\
(5.0 \%)\end{array}$ & $\begin{array}{c}29 \\
(4.8 \%)\end{array}$ & $\begin{array}{c}3 \\
(0.5 \%)\end{array}$ & $\begin{array}{c}2 \\
(0.3 \%)\end{array}$ & $\begin{array}{c}15 \\
(2.5 \%)\end{array}$ & $\begin{array}{c}79 \\
(13.2 \%)\end{array}$ \\
\hline & II $^{\circ}$ & $\begin{array}{c}11 \\
(1.8 \%)\end{array}$ & $\begin{array}{c}51 \\
(8.5 \%)\end{array}$ & $\begin{array}{c}8 \\
(1.3 \%)\end{array}$ & $\begin{array}{c}12 \\
(2.0 \%)\end{array}$ & $\begin{array}{c}43 \\
(7.2 \%)\end{array}$ & $\begin{array}{c}125 \\
(20.9 \%)\end{array}$ \\
\hline 耳 & III $^{\circ}$ & $\begin{array}{c}2 \\
(0.3 \%)\end{array}$ & $\begin{array}{c}2 \\
(0.3 \%)\end{array}$ & $\begin{array}{c}5 \\
(0.8 \%)\end{array}$ & $\begin{array}{c}8 \\
(1.3 \%)\end{array}$ & $\begin{array}{c}319 \\
(53.3 \%)\end{array}$ & $\begin{array}{c}336 \\
(56.2 \%)\end{array}$ \\
\hline \multirow[t]{2}{*}{ 症 } & $\mathbb{N}^{\circ}$ & $(0.3 \%)$ & $(0.3 \%)$ & $\begin{array}{c}4 \\
(0.7 \%)\end{array}$ & 0 & $\begin{array}{c}44 \\
(7.4 \%) \\
\end{array}$ & $\begin{array}{c}51 \\
(8.5 \%) \\
\end{array}$ \\
\hline & $\mathrm{V}^{\circ}$ & 0 & $(0.2 \%)$ & 0 & 0 & $\begin{array}{c}6 \\
(1.0 \%)\end{array}$ & $\begin{array}{c}7 \\
(1.2 \%)\end{array}$ \\
\hline & Total & $\begin{array}{c}45 \\
(7.5 \%)\end{array}$ & $\begin{array}{c}84 \\
(14.0 \%)\end{array}$ & $\begin{array}{c}20 \\
(3.3 \%)\end{array}$ & $\begin{array}{c}22 \\
(3.7 \%)\end{array}$ & $\begin{array}{c}427 \\
(71.4 \%)\end{array}$ & 598耳 \\
\hline
\end{tabular}


重度の傾向にあるようであった。

4 ）他部位の奇形の合併頻度

聴器周辺の奇形である副耳は同側43例, 他側 22 例, 両側 3 例, 計68例（12.3\%）と比較的頻 度にみられた。他にも，先天性耳瘻孔，耳垂裂， 折れ耳，カップ耳などがみられた（表 4).

また，第 1 ，第 2 鰓弓症候群が 21 例みられた。 その中には下顎の形成不全のみで，巨口症を伴 わないものが12例含まれている。他にも， Treacher-Collins 症候群が 5 例, dermoid ある いは上眼瞼の欠損，耳介異常括よび耳介前部の 皮膚隆起, 春椎の異常を 3 主徵とする Goldenhar 症候群と思われる症例が 1 例みられた。

表 4 合併した外耳奇形の頻度

\begin{tabular}{llr}
\hline \hline 外耳道奇形 & 閉鎖 & $469(78.4 \%)$ \\
& 狭窄 & $84(14.0 \%)$ \\
& 他側狭窄 & $5(0.9 \%)$ \\
副耳 & 同側 & $43(7.8 \%)$ \\
& 他側 & $22(4.0 \%)$ \\
先天性耳瘻孔 & 両側 & $3(0.5 \%)$ \\
& 同側 & $10(1.8 \%)$ \\
& 他側 & $2(0.4 \%)$ \\
耳垂裂 & 両側 & $2(0.4 \%)$ \\
& 同側 & $1(0.2 \%)$ \\
折れ耳 & 他側 & $2(0.4 \%)$ \\
カップ耳 & 他側 & $3(0.5 \%)$ \\
& 同側 & $1(0.2 \%)$ \\
& 他側 & $2(0.4 \%)$ \\
& 両側 & $1(0.4 \%)$
\end{tabular}

また，同側の顔面神経麻㽻が13例に，軟口蓋 裂が 6 例，唇，口蓋裂が 3 例に，心奇形が 7 例 に合併していた，染色体異常と思われる症例は， みられなかった（表 5 ）。

\section{5 ) 遺伝的関係}

父親の小耳症例が 3 例みられた。 1 例は父親 が第 II 度小耳症で，次男が右の第而度小耳症， 1 例は父親が左の第 I 度小耳症で，長男が左の 第 $\mathbb{N}$ 度小耳症，も51 例は父親が左小耳症で, 長女が左正度, 右正度の両側小耳症であった。 その他, 従兄弟が同側の小耳症が 2 例, 父の叔

表 6 遺伝的関係

\begin{tabular}{l}
\hline \multicolumn{3}{c}{ 〈小耳症の家族内発症〉 } \\
父親
\end{tabular}

表 5 その他の合併症の頻度

\begin{tabular}{|c|c|c|c|}
\hline 第 1 , 第 2 鰓弓症候群 & $21(3.8 \%)$ & 下顎骨肥大 & $1(0.2 \%)$ \\
\hline Treacher-Collins 症候群 & $5(0.9 \%)$ & 巨口症（対側） & $1(0.2 \%)$ \\
\hline Goldenhar 症候群 & $1(0.2 \%)$ & 顔面血管腫(同側) & $1(0.2 \%)$ \\
\hline 顔面神経麻瘒（同側） & $13(2.4 \%)$ & 斜頸 & $2(0.4 \%)$ \\
\hline 斜視（同側） & $3(0.5 \%)$ & 心奇形 & $7(1.3 \%)$ \\
\hline （他側） & $1(0.2 \%)$ & 漏斗胸 & $1(0.2 \%)$ \\
\hline （左右不明） & $1(0.2 \%)$ & 资椎破裂 & $2(0.4 \%)$ \\
\hline 眼裂狭小 & $1(0.2 \%)$ & 先天性股関節脱臼 & $1(0.2 \%)$ \\
\hline 軟口蓋運動障害（同側） & $7(1.3 \%)$ & 重複拇指（同側） & $1(0.2 \%)$ \\
\hline 軟口蓋裂 & $6(1.1 \%)$ & その他 & $3(0.5 \%)$ \\
\hline 唇・口蓋裂 & $3(0.5 \%)$ & & \\
\hline
\end{tabular}


父，母の従兄弟に小耳症がみられた症例が各 1 例みられた。 また, 父親が両側カップ耳で, 長 女が右の第吕度小耳症, 父親が右カップ耳で, 次男が右の第II度小耳症, 父親が両側軽度の力 ップ耳で, 長男が右而度, 左 I 度が各 1 例みら れ，血縁内に何らかの耳介奇形がみられるもの が10例存在した。 また血縁内の唇, 口蓋裂が 6 例にみられた．X染色体性遺伝である血友病が 母と姉にみられた症例が 1 例存在した（表 6 ）.

6 ）母胎妊娠中の異常および薬物療法

この調査に打いて妊娠中に異常を生じた母親 は549名中147名（26.8\%）であり，耳介が形成
される妊娠初期の感冒罹患, 切迫流産, 妊娠中 毒症などが，比較的高頻度にみられた（表 7 ）。

また妊娠中の異常に伴う薬物療法については, 感冒治療薬, 流産予防薬, 酔い止め, 抗生物質, 鎮痛剂などがみられたが，明らかな因果関係を 証明するには，正常児を産んだ母親の集団との 比較が必要である。すでに，明らかな因果関係 が証明されているサリドマイドを妊娠初期に服 用していた症例が 2 例みられた（表 8 ）.

\section{考察}

従来小耳症は男性に多く，右側に多いとされ ている.福田ら ${ }^{7)}$ は1207例で, 右側 $63 \%$, 左側 37

表 7 妊娠中の異常（総症例549例）

\begin{tabular}{|c|c|c|c|c|c|c|}
\hline & $\sim 3 \mathrm{M}$ & $4 \sim 6 \mathrm{M}$ & $7 \mathrm{M} \sim$ & 不明 & \multicolumn{2}{|c|}{ TOTAL } \\
\hline 感冒罹患 & 32 & 4 & 4 & 3 & 43 & $(7.8 \%)$ \\
\hline 切迫流産 & 20 & 5 & 3 & 3 & 31 & $(5.7 \%)$ \\
\hline 妊娠中毒症 & 12 & 1 & 10 & 2 & 25 & $(4.5 \%)$ \\
\hline 貧血 & 1 & 3 & 3 & 6 & 13 & $(2.4 \%)$ \\
\hline 転倒腹部打撲 & 2 & 4 & 2 & 0 & 8 & $(1.5 \%)$ \\
\hline 風疹 & 1 & 0 & 0 & 0 & 1 & $(0.2 \%)$ \\
\hline その他 & 9 & 2 & 2 & 13 & 26 & $(4.7 \%)$ \\
\hline 合計 & 77 & 19 & 24 & 27 & 147 & $(26.8 \%)$ \\
\hline
\end{tabular}

表 8 妊娠中の薬物療法

\begin{tabular}{|c|c|c|c|c|c|c|}
\hline 薬 & 妊娠前後 & $\sim 3 \mathrm{M}$ & $4 \mathrm{M} \sim 6 \mathrm{M}$ & $7 \mathrm{M} \sim$ & 不明 & Total \\
\hline 流産予防薬 & 0 & 9 & 4 & 1 & 2 & 16 \\
\hline 鎮痛剂 & 1 & 4 & 0 & 0 & 0 & 5 \\
\hline 乗り物酔いの薬 & 0 & 6 & 1 & 1 & 1 & 9 \\
\hline 睡眠薬 & 0 & $3^{*}$ & 1 & 1 & 0 & $5^{*}$ \\
\hline 抗貧血剂 & 0 & 1 & 3 & 3 & 2 & 10 \\
\hline 感冒治療薬 & 0 & 11 & 2 & 2 & 2 & 17 \\
\hline 抗生物質 & 0 & 5 & 0 & 1 & 0 & 6 \\
\hline 精神安定剤 & 0 & 1 & 0 & 0 & 0 & 1 \\
\hline 下剤 & 0 & 1 & 0 & 0 & 0 & 1 \\
\hline 抗ヒスタミン斉 & 0 & 1 & 0 & 0 & 1 & 2 \\
\hline 降圧剂 & 0 & 0 & 0 & 0 & 1 & 1 \\
\hline 漢方薬 & 0 & 0 & 0 & 0 & 1 & 1 \\
\hline 不妊症治療薬 & 2 & 0 & 0 & 0 & 0 & 2 \\
\hline インスリン & 1 & 0 & 0 & 0 & 0 & 1 \\
\hline
\end{tabular}

*サリドマイド（2）を含む 
$\%$, 両側 $7.7 \%$, 男女比 $7: 3$, 牧島 ${ }^{8)}$ は174例 で右側 $60 \%$, 左側 $29 \%$, 両側 $10 \%$, 男女比約 7 : 3 , 菅谷ら ${ }^{9)}$ は537例で，右側 $54 \%$, 左側 $36 \%$, 両側10\%, 男女比 2:1, Meurmann ${ }^{10)}$ は82例で 右側 $60 \%$, 左側 $40 \%$, 男女比約 $2: 1$ と報告し ている，われわれの集計でも男性 $64.1 \%$ ，女性 $35.9 \%$ で男女比 $9: 5$ と男性に多く, 右側 58.1 $\%$, 左側 $33.0 \%$, 両側 $8.9 \%$ と右側に多く発現 し，諸家の報告と一致する.

小耳症の耳介変形の程度はさまざまであるが,

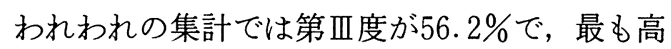
頻度にみられた。福田らは耳垂型 (peanut ear) $59 \%$ ，菅谷らは第而度が $58 \%$ と報告して拈り， われわれと同結果である。

耳介の発生には，第 1 , 第 2 鰓弓と第 1 鰓溝 の一部が関与して，第 12 週頃形状ができあがり， また第 1 鰓溝は外耳道の原基ともなり第28週頃 に完成するといわれている.ゆえに外耳道の耳 介の発生は, 密接に関連し, 奇形発生に相関が あって当然である11). 小耳症の多くに外耳道の 狭窄ないし閉鎖を合併することについて，小 倉 ${ }^{12)}$ は445耳の $94 \%$ ，菅野らは537耳の $92.7 \%$ と報告しているが，われわれの集計でも $92.4 \%$ と高率であった。をた, 第 $\mathrm{V}$ 度, $\mathrm{V}$ 度の小耳症 に, 外耳道の開存例, 狭窄例もみられたが, だ いたい耳介と外耳道の奇形度は平行するといら 結果がえられた.

第 1 鰓弓からは, 上顎骨, 頓骨, 下顎骨, 上 下唇, 耳輪, 耳珠, 棺骨, 砧骨が, 第 2 鰓弓か らは耳輪後部, 鐙骨, 耳筋が発生する. 第 1 , 第 2 鰓弓由来の骨や軟部組織の発育障害により, 顔貌がいびつになっているものは第 1 , 第 2 鰓 弓症候群とよばれる. Tanzer ${ }^{13)}$ は, 小耳症の 約半数が第 1 , 第 2 鰓弓症候群の徵候を伴って いると述べているが，当教室では，第 1 , 第 2 鰓弓症候群と思われる症例は549例中 21 例であ った。

小耳症は，第 1 ，第 2 鰓弓の発育が抑制され るために怙こると考えられるが，発育過剩であ る副耳の合併も諸家により報告されており
われわれの集計でも68例と多かった.

他の合併奇形として, 菅谷らは耳瘦孔, 顔面 神経麻痺, 心奇形などをあげているが，当教室 でも多くみられた。

先天異常は一部は遺伝 $(20 \%)$, 他の一部は 環境要因から（ $5 \%)$, 残りの大半は両者が複 雑に絡み合って生じるとされている，遺伝疾患 は大きく分類すると, 単一遺伝子病（メンデル 遺伝), 染色体異常, 多因子遺伝病にわけられ る. 西村 ${ }^{14)}$ は小耳症の発生の成因について, 1 ) 単一遺伝子によるもの，2）染色体異常, 3 ）サリドマイド, 葉酸拮抗剤など特定の環境 因子が主因をなしたもの，4）散発性で遺伝と 環境要因の合併によるもの，の 4 つに分類し， 散発性に現われたもののらち, 優性遺伝性の突 然変異の初発にあたる Treacher-Collins 症候群 以外は，4）に属するだろうと述べている. 高

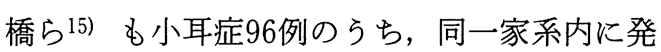
症した小耳症 7 例を報告し，これまで知られて いる遺伝形式, 寸なわち, 常染色体優性遺伝, 常染色体劣性遺伝, 伴性遺伝, 染色体異常, 多 因子遺伝のそれぞれの特徵と対比し, 多因子遺 伝の可能性を強く示唆している。をた，菅谷 ら16) は, 低い同胞発現率や家族歷から多因子 遺伝に対して否定的で, 環境因子を発生原因と 考光ている.

多因子遺伝の特徵として ${ }^{17)}$,

1) ありふれた疾患が多い（0.1〜 1\%)

2 ）一般集団頻度がPのとき，1度近親の再 発危険率は $\sqrt{\mathrm{P}}$

3 ）性差がしばしばみられる

4 ）低頻度の性の患者の近親に打ける再発率 の方が高い

5） 1 度近親中の患者数が増すにつれて, 再 発率は急激に上昇する

6 ）奇形の重症度が重いほど再発率が高い

7 ）近親度の減少につれて再発率は激減する があげられる. 今回の集計に括いて 1 度近親に 現われたのは 549 例中 3 例で, 再発率は $0.5 \%$ で あった. 小耳症の場合, 黒木らのデータでは一 
般人口頻度 $0.021 \%$, 平方根の值は $1.4 \%$ となり, 1)，2）に合致しない.また 3 例とも父親で 4) もあてはまらない。しかし遺伝的要因も否定し えないように思われる。

胎生期に器官形成障害を及洔す環境因子には, 化学物質, 薬剤, 放射線, ウイルスなどが考兄 られている。薬剤などの化学的要因が原因とな るのは，先天異常の $1 \%$ 以下と推定されている が，薬剤の催奇性を証明するのは極めて困難で ある。

今回の集計に拈いて，妊娠中異常を生じた母 親は，549例中147例（26.8\%）で，感冒罹患， 切迫流産, 妊娠中毒症, 貧血などが多くみられ た. 菅谷らも $37.7 \%$ に妊娠中の異常がみられ， 切迫流産, 感冒, 妊娠中毒症などが多かったと 報告している。また 7 月， 9 月，10月の出産例 に小耳症の発生数が多く，妊娠初期が感冒が流 行している時期であるためウイルス感染の可能 性も示唆している.

家族内発生の報告は，本邦では他に松本ら ${ }^{18)}$ が親子例, 兄弟例を各 1 例, 早崎ら ${ }^{19)}$ が親子 例を 2 例, 福田らが兄弟例を 2 例のみで, 少な く，菅谷らが述べるように，多因子遺伝の特徵 に合致しない点があるが, 右側, 男性に多い傾 向がみられ，他の奇形と合併することが少ない など，環境因子のみでは説明できない部分があ り，今後さらに検討を加える必要があると思わ れる。

$$
\text { まとめ }
$$

昭和 42 年より平成 2 年までの約 23 年間に名古 屋市立大学病院耳鼻咽喉科を受診した小耳症患 者549例，598耳について，さまざまな角度から， 統計学的検討を行なった.

性別は, 男性 (64.1\%), 罹患側は右側 (58.1\%) に多かった。

变形度は, 第血度 (peanut-shell type) が最も 多く $(56.2 \%)$, 合併する奇形は, 外耳道の狭 窄ないし閉鎖が圧倒的に多く $(92.4 \%)$, 耳介 と外耳道間の奇形度には，およその相関がみら れた。
家族内に発生した小耳症は 7 例みられ，親子 例は 3 例で全て父親であった。

母親の妊娠中の異常として, 感冒, 切迫流産, 妊娠中毒症, 貧血などが多くみられた.

Treacher-Collins 症候群に合併した 5 例, 妊 娠中のサリドマイド服用 2 例以外は, 遺伝, 環 境因子など，明らかな因果関係を証明する原因 は得られなかった。

\section{文献}

1) Holmes EM : The microtic ear. Arch Otolaryngol $49: 243,1949$.

2) Conway $\mathrm{H}$ and Wagner $\mathrm{KJ}$ : Congenital anomalies of the head and neck. Plast Recontr Surg 36 : 71 79, 1965.

3) Fukuda $0:$ The microtic ear; survey of 180 cases in 10 years. Plast Recontr Surg $53: 458$ $\sim 463,1974$.

4）黒木良和, 小西 宏, 角田昭夫, 他: 神奈川県 における先天的異常モニタリング.こども医療 センター医学誌 13：143〜155, 1984.

5）荻野洋一, 酒井成身: 耳介の先天異常. 産婦人 科の世界 31：11 22, 1979.

6）太田文彦, 細田岩雄, 文珠敏郎, 他: 中耳所見 からみた先天的外耳奇形.耳鼻臨床 $58: 501$ 510, 1965.

7) 福田 修, 岡部勝行, 望月政彦, 他: 小耳症の 統計学的観察. 日形会誌 4:747 748, 1984.

8）牧島和見, 徳永 修: 先天性外耳奇形の統計学 的観察. 耳鼻 $12: 115 \sim 125,1966$.

9）菅谷良男, 武田道樹, 荻野洋一, 他：537名の 小耳症患者の統計的観察. 日形会誌 $4: 899 \sim$ 909, 1984.

10) Meurmann $Y$ : Congenital microtia and meatal atresia (observation and aspect of treatment). Arch Otolaryngol 66 : 443 463, 1957.

11）西村善彦: 小耳症と外耳道閉鎖症. 形成外科 $32: 9 ; 969 \sim 980,1989$.

12）小倉義郎：伝音系奇形一その基礎的研究と手術. 耳鼻展望 22 補 $2: 124,1979$.

13) Tanzer RC : Congenital deformities. Reconstructive Plastic Surgery (ed by JM Converse) Vol. 3. pp 1073 1106, WB Saunders Co, Philadelphia, 1964. 
14）西村秀雄 : 小耳症の発生. 形成外科 $17: 453$ 459, 1974.

15）高橋 元，前田華郎：同一家系にみられた小耳 症の 7 例. 形成外科 $25: 301 \sim 319,1982$.

16）菅谷良男, 武田道樹, 荻野洋一：537例の小耳 症患者の統計的観察. 日形会誌 $5: 173 \sim 187$, 1985.

17）黑木良和：遣伝相談. 今日の小児治療指針第 7 版. 109 111頁, 医学書院, 東京, 1987.
18）松本維明 : 外耳奇形. 標準形成外科（鬼塚卓也 編). 194頁, 医学書院, 東京, 1975.

19）早崎弘晃 : 先天的外耳道閉鎖症の遺伝学的研究. 日耳鼻 $62 ： 1836 \sim 1844,1959$. 厂467 名古屋市瑞穂区瑞穂町川澄 1

名古屋市立大学医学部耳鼻咽喉科学教室) 